\title{
Hubungan Tingkat Kecerdasan Spiritual Dan Kecerdasan Sosial Terhadap Self Efficacy Pada Siswa Kelas XI di MAN 4 Madiun
}

\author{
Ullin Nuril Farida' ${ }^{1}$, Badrus ${ }^{2}$ \\ 1Pascasarjana Institut Agama Islam Tribakti Kediri, ${ }^{2}$ Institut Agama Islam Tribakti Kediri \\ 1ullinnuril@gmail.com, 2badrus.kdr@gmail.com
}

\begin{abstract}
Learning concentration becomes an important requirement in learning activities. This should be the concern of all educators, if they want to achieve their educational goals. In this context, this research with the theme of spiritual intelligence, social intelligence and self efficacy in solving a problem is very important to be implemented. This research is a quantitative research. The population in this study all students of class XI in Senior High School 4 Madiun, amounting to 136 students, because more than 100, the study used a sample of 34 students. The data collection techniques use documentation and questionnaires. The analysis technique uses multiple linear analysis, the coefficient of determination, which is preceded by an assumption test of analysis, namely the validity test, reliability test, normality, linearity test and hypothesis test. This study wants to see, [1] the relationship of spiritual intelligence to self efficacy, [2] the relationship of social intelligence to self efficacy, and [3] the relationship of spiritual intelligence and social intelligence to self efficacy in class XI Senior High School 4 Madiun. The results of this study indicate that: [1] significant influence between spiritual intelligence on self efficacy, denger regression coefficient of spiritual intelligence variable is 0.694 [2] significant influence of social intelligence on self efficacy, with regression coefficient of social intelligence variable of 0.543 and [3] significant influence spiritual intelligence and social intelligence together towards self efficacy.
\end{abstract}

Keywords: Spiritual Intelligence, Social Intelligence, Self Efficacy.

\begin{abstract}
Abstrak
Konsentrasi belajar menjadi kebutuhan penting dalam kegiatan pembelajaran. Hal ini harus menjadi perhatian semua pebyelenggara pendidikkan, jika ingin mencapai tujuan pendidikan. Dalam konteks inilah, penelitian ini dengan tema kecerdasan spiritual, kecerdasan sosial dan self efficacy dalam pemecahan sebuah masalah sangat penting dilaksanakan. Penelitian ini merupakan penelitian kuantitatif. Populasi dalam penelitian ini semua siswa kelas XI di MAN 4 Madiun yang berjumlah 136 siswa, oleh karena lebih dari 100 maka penelitiannya menggunakan sampel sejumlah 34 siswa. Adapun teknik pengumpulan data menggunakan dokumentasi dan angket. Teknik analisis menggunakan analisis linier berganda, koefisien determinasi, yang didahului dengan uji asumsi analisis yaitu uji validitas, uji reliabilitas,
\end{abstract}


normalitas, uji linieritas dan uji hipotesis. Penelitian ini ingin melihat, [1] hubungan kecerdasan spiritual terhadap self efficacy, [2] hubungan kecerdasan sosial terhadap self efficacy, dan [3] hubungan kecerdasan spiritual dan kecerdasan sosial terhadap self efficacy pada kelas XI di MAN 4 Madiun. Hasil penelitian ini menunjukkan bahwa: [1] pengaruh signifikan antara kecerdasan spiritual terhadap self efficacy, dengen Koefisien regresi variabel kecerdasan spiritual sebesar 0.694 [2] pengaruh signifikan kecerdasan sosial terhadap self efficacy, dengan Koefisien regresi variabel kecerdasan sosial sebesar 0.543 dan 3) pengaruh signifikan kecerdasan spiritual dan kecerdasan sosial secara bersama-sama terhadap self efficacy.

Kata kunci: Kecerdasan Spiritual, Kecerdasan Sosial, Self Efficacy.

\section{Pendahuluan}

Tercapainya tujuan pendidikan, tidak bisa dilepaskan dari aspek konsentrasi belajar. Konsentrasi belajar merupakan suatu kefokusan diri pribadi peserta didik terhadap mata pelajaran ataupun aktivitas belajar. Dalam aktivitas belajar seharusnya dibutuhkan konsentrasi penuh, untuk mendapatkan hasil maksimal. Akan tetapi dalam kenyataan keseharian masih banyak masalah kurangnya konsentrasi belajar peserta didik. Faktor dari permasalahan tersebut diantaranya adalah kurangnya manajemen waktu, kondisi kesehatan, kurang minat terhadap mata pelajaran, adanya masalah pribadi atau masalah keluarga, dan cara penyampaian materi oleh guru yang kurang menarik. Karena adanya faktor penyebab tersebut pasti juga adanya dampak negatif untuk peserta didik sendiri. ${ }^{1}$

Dampak negatif tersebut diantaranya adalah kurangnya pemahaman terhadap mata pelajaran,

${ }^{1}$ Indragiri. A., Kecerdasan Optimal: Cara Ampuh memaksimalkan Kecerdasan Anak, (Jogjakarta: Starbooks, 20100, hal. 120 tidak memperhatikan pemaparan materi di kelas, sikap cuek dengan situasi kelas, dan juga tidak memperhatikan tugas yang diberikan. Oleh karena itu kecerdasan yang dimiliki oleh siswa sangat mempengaruhi bagaimana suatu materi yang disajikan dapat dipahami dan diminati, terutama kecerdasan spiritual dan kecerdasan sosial.

Masa remaja awal itu tidak lepas dari kecerdasan spiritual, kecerdasan sosial dan self efficacy dalam pemecahan sebuah masalah. Dimana remaja awal ini masih dalam masa sangat labil atau belum stabil dalam menghadapi permasalahan. Perilaku atau tindakan yang dimunculkan oleh setiap individu tergantung dari fikiran yang dimunculkan sebelum mereka akan memutuskan untuk bertindak. ${ }^{2}$

Efikasi diri secara umum berhubungan dengan harga diri (self esteem) karena keduanya merupakan aspek dari penilaian yang berkaitan

2 Zohar Danah. dan Marshall, S.. SQ, Memanfaatkan Kecerdasan Spiritual Dalam Berpikir Integralistik dan Holistik untuk Memaknai Kehidupan, (Bandung: Mizan, 20011), hal, 67 
dengan kesuksesan atau kegagalan. Seseorang dengan efikasi diri tinggi percaya bahwa mereka mampu melakukan sesuatu untuk mengubah kejadian-kejadian di sekitarnya, serta mampu bersosialisasi dengan lingkungannya. Sedangkan seseorang dengan efikasi diri rendah menganggap dirinya pada dasarnya tidak mampu mengerjakan segala sesuatu yang ada disekitarnya. Dalam situasi yang sulit, orang dengan efikasi yang rendah cenderung mudah menyerah dan tidak memiliki semangat untuk bangkit. Sementara orang dengan efikasi diri yang tinggi akan berusaha lebih keras untuk mengatasi tantangan yang ada sehingga dia dapat bangkit kembali dan mencapai kesuksesan. ${ }^{3}$

Beberapa penelitian menunjukkan bahwa perubahan pola kehidupan generasi kita menjadi pribadi yang individual, materialis, dan cenderung kapitalis. Bahkan beberapa penelitian menunjukkan bahwa tidak semua mereka yang berkedudukan tinggi memiliki kecerdasan spiritual yang tinggi. Kecerdasan spiritual merupakan kemampuan jiwa yang dimiliki seseorang untuk membangun dirinya secara utuh melalui berbagai kegiatan positif sehingga mampu menyelesaikan berbagai persoalan dengan melihat makna yang terkandung didalamnya.

Fokus penelitian ini di sektor pendidikan yang ada di wilayah Madiun, yaitu di MAN 4 Madiun. Alasan mengambil sektor tersebut,

${ }^{3}$ Zohar, Danah dan Marshall, Ian. SQ: Kecerdasan Spiritual. Terjemahan (SQ) Spiritual karena di MAN 4 Madiun telah berlangsung kegiatan terprogram yaitu kegiatan yang dilaksanakan secara bertahap disesuaikan dengan jadwal yang telah ditetapkan lembaga tersebut. Penelitian ini hendak menjawab: [1] hubungan kecerdasan spiritual terhadap self efficacy, [2], hubungan kecerdasan sosial terhadap self efficacy dan [3] hubungan kecerdasan spiritual dan kecerdasan sosial terhadap self efficacy.

\section{Metode}

Penelitian ini merupakan jenis penelitian kuantitatif, karena peneliti berusaha memperoleh data informasi yang berkaitan dengan fenomena yang diamati. Pendekatan yang digunakan dalam penelitian ini adalah pendekatan kuantitatif dengan metode regresi linier berganda.

Penelitian ini mengkaji kontribusi kecerdasan spiritual siswa MAN 4 Madiun kelas XI (X1) dan kecerdasan sosial siswa kelas XI (X2) sebagai variabel bebas atau prediktor dan self efficacy siswa kelas XI (Y) sebagai variabel terikat atau kriterium. Populasi penelitian ini adalah semua siswa MAN 4 Madiun kelas XI yang berjumlah 136 siswa. Mengingat jumlah populasi ini ada 136 siswa atau lebih dari 100, maka penulis mengambil 25\% dari jumlah siswa tersebut yaitu sebanyak 34 siswa untuk dijadikan sampel yaitu sebanyak 21 siswa perempuan dan 13 siswa laki-

Intelligence - The Ultimate Intelligence, (Bandung: Mizan Pustaka, 2000), hal 172 
laki, sehingga penelitian ini disebut penelitian sampel.

\section{Pembahasan}

\section{Kecerdasan Spiritual}

Menurut para ahli, ada banyak kecerdasan yang diberikan oleh Tuhan kepada manusia. Salah satunya yaitu kecerdasan spiritual (SQ), kecerdasan ini merupakan kecerdasan yang mengangkat fungsi jiwa sebagai perangkat internal diri yang memiliki kemampuan dan kepekaan dalam melihat makna yang ada di balik sebuah kenyataan atau kejadian tertentu. Kecerdasan spiritual (SQ) yang sangat terkait dengan persoalan makna dan nilai ini pertama kali digagas dan ditemukan oleh Danah Zohar dan Ian Marshall.

Menurut Danah Zohar dalam bukunya Akhmad Muhaimin: "Menilai bahwa kecerdasan spiritual merupakan bentuk kecerdasan tertinggi yang memadukan kedua bentuk kecerdasan sebelumnya, yakni kecerdasan intelektual dan kecerdasan emosional. Kecerdasan spiritual dinilai sebagai kecerdasan yang tertinggi karena erat kaitannya dengan kesadaran orang untuk bisa memaknai segala sesuatu dan merupakan jalan untuk bisa merasakan kebahagiaan." ${ }^{4}$

Menurut Mas Udik Abdullah, "Kecerdasan spiritual adalah kecerdasan yang membuat seseorang

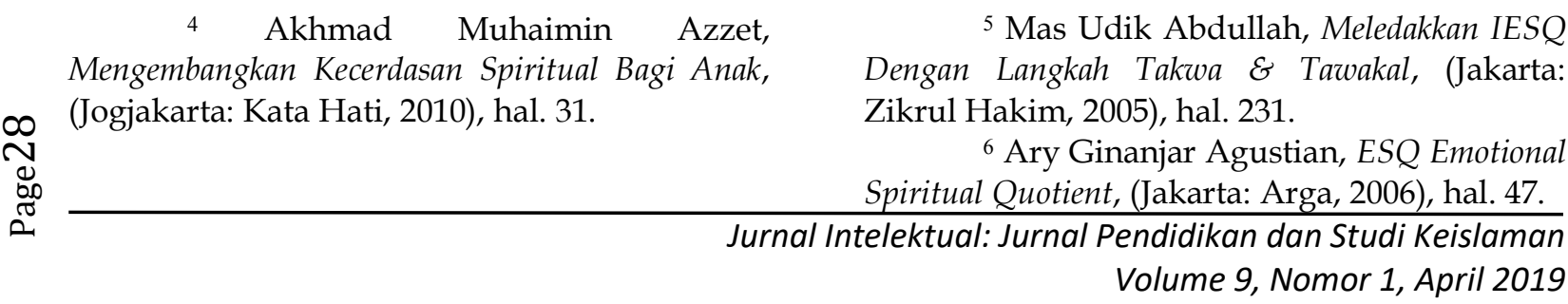

menjadi utuh, sehingga dapat mengintegrasikan berbagai fragmen kehidupan, aktifitas dan keberadaannya. Kecerdasan spiritual memungkinkan seseorang dapat mengetahui apa sesungguhnya dirinya dan organisasinya. Kecerdasan spiritual memungkinkan lahirnya wawasan dan pemahaman untuk beralih dari sisi dalam ke permukaan keberadaan seseorang, tempat seseorang bertindak, berpikir dan merasa. Kecerdasan spiritual juga menolong seseorang untuk berkembang." 5

Sedangkan menurut Ali Ginanjar, "Spiritual Quotient adalah Kemampuan seseorang untuk dapat mengimplementasikan nilai-nilai agama sebagai pusat keyakinan dan landasan untuk melakukan segala sesuatu yang benar dengan benar dan kegiatan serta mampu menyinergikan IQ, EQ dan SQ secara komprehensif."6

Berdasarkan pendapat para ahli di atas, peneliti dapat menarik kesimpulan bahwa kecerdasan spiritual adalah kecerdasan yang dibangun dari dua kecerdasan, yakni intelektual dan emosional. Orang yang memiliki kecerdasan spiritual adalah orang yang bisa memecahkan permasalahan tidak hanya menggunakan rasio dan emosi saja, namun mereka menghubungkan dengan makna kehidupan secara spiritual. Kecerdasan spiritual yang 
tumbuh sejak dini akan menjadi kekuatan untuk menjadikan anak yang berani karena keyakinan kepada Tuhan, optimis, dan melakukan kebajikan secara terus menerus.

\section{Kecerdasan Sosial}

Kecerdasan sosial adalah kemampuan individu untuk menghadapi dan mereaksi situasi-situasi sosial atau hidup di masyarakat. Kecerdasan sosial bukan emosi seseorang terhadap orang lain, melainkan kemampuan seseorang untuk mengerti kepada orang lain, dapat berbuat sesuatu dengan tuntutan masyarakat.

Menurut Prawira, Individu dengan kecerdasan sosial yang tinggi akan mampu berinteraksi, bergaul, atau berkomunikasi dengan orang lain secara mudah, mampu menyesuaikan diri dalam berbagai lingkungan sosial budaya. $^{7}$

Menurut Indragiri, "Kecerdasan sosial adalah kemampuan untuk mengamati dan mengerti maksud, motivasi, dan perasaan orang lain. Orang yang memiliki kecerdasan sosial peka dengan ekspresi wajah, suara, dan gerakan tubuh orang lain dan mampu memberikan respons secara efektif dalam berkomunikasi. Kecerdasan sosial melibatkan kemampuan untuk memahami orang lain, baik di dalam dunia pandangan, maupun perilakunya." 8

Menurut Hariwijaya," Kecerdasan sosial berhubungan dengan kemampuan seseorang dalam membangun interaksi bersama orang lain. Banyak orang yang gagal dalam berinteraksi di dalam masyarakat. Sebaliknya banyak orang yang tampil mempesona dan menjadi tauladan orang banyak. Hal ini berkaitan dengan kecerdasan seseorang dalam hal sosial." 9

Menurut Hamzah, “Kecerdasan sosial menunjukkan kemampuan seseorang untuk peka terhadap perasaan orang lain. Mereka cenderung memahami dan berinteraksi dengan orang lain, sehingga mudah bersosialisasi dengan lingkungan di sekelilingnya. Kecerdasan semacam ini juga sering disebut sebagai kecerdasan sosial, yang selain kemampuan menjalin persahabatan yang akrab dengan teman, juga mencakup kemampuan, seperti memimpin, mengorganisasi, menangani perselisihan antarteman, memperoleh simpati dari peserta didik yang lain, dan sebagainya." 10

Dari beberapa pengertian tentang kecerdasan sosial di atas, maka peneliti dapat menarik kesimpulan bahwa kecerdasan sosial adalah kemampuan individu dalam menyesuaikan diri dengan lingkungannya, dalam mengha-

10 Hamzah B. Uno dan Nurdin Mohamad, Belajar dengan Pendekatan PAILKEM: Pembelajaran Aktif, Inovatif, Lingkungan, Kreatif, Efektif, Menarik, (Jakarta: PT Bumi Aksara, 2012), hal. 245-246.
7 Prawira, hal. 151-152.

${ }^{8}$ Indragiri.A,... hal. 17.

9 M. Hariwijaya dan Sutan Surya, Adventures in Math: Tes IQ Matematika, (Yogyakarta: Tugu Publisher, 2007), hal. 15. 
dapi situasi dan masalah di sekitarnya, mengamati dan memahami perasaan orang lain serta membangun hubungan baik yang saling menguntungkan.

\section{Self Efficacy}

Efikasi diri (self efficacy) adalah keyakinan individu mengenai kemampuan dirinya dalam melakukan tugas atau tindakan yang diperlukan untuk mencapai hasil tertentu. ${ }^{11}$

Menurut Alwiso, "Self efficacy adalah persepsi diri sendiri mengenai seberapa bagus diri dapat berfungsi dalam situasi tertentu. Self efficacy berhubungan dengan keyakinan diri memiliki kemampuan melakukan tindakan yang diharapkan. Self efficacy adalah penilaian diri, apakah dapat melakukan tindakan yang baik atau buruk, tepat atau salah, bisa atau tidak bisa mengerjakan sesuai dengan yang dipersyaratkan. Self efficacy berbeda dengan aspirasi (cita-cita), karena citacita menggambarkan sesuatu yang ideal yang seharusnya (dapat dicapai), sedangkan self efficacy menggambarkan penilaian kemampuan diri." 12

Menurut Bandura, "Self efficacy merupakan konstruk yang diajukan Bandura yang berdasarkan teori sosial kognitif. Dalam teorinya, Bandura menyatakan bahwa tindakan manusia merupakan suatu hubungan yang timbal balik antara individu,

${ }^{11} \mathrm{~J}$. Feist, dan G.J Feist, Theories of Personality, Fourth Edition, (Boston: Mcgraw-Hill Companies Inc., 1998), hal 35

12 Alwisol, Psikologi Kepribadian, UMM Press: Malang, 2007, hal. 287. lingkungan, dan perilaku (triadic reciprocal causation). ${ }^{13}$

Teori self efficacy merupakan komponen penting pada teori kognitif sosial yang umum, di mana dikatakan bahwa perilaku individu, lingkungan dan factor-faktor kognitif (misalnya, pengharapan-pengharapan terhadap hasil dan self efficacy) memiliki saling keterkaitan yang tinggi.

Menurut Gibson et al., "Konsep self efficacy atau keberhasilan diri merupakan keyakinan bahwa seseorang dapat berprestasi baik dalam situasi tertentu. Keberhasilan diri mempunyai tiga dimensi yaitu: tingginya tingkat kesulitan tugas seseorang yang diyakini masih dapat dicapai, keyakinan pada kekuatan, dan generalisasi yang berarti harapan dari sesuatu yang telah dilakukan." 14

Dari beberapa pengertian di atas, dapat penulis simpulkan bahwa self efficacy adalah keyakinan individu dalam menghadapi dan menyelesaikan masalah yang dihadapinya diberbagai situasi serta mampu menentukan tindakan dalam menyelesaikan tugas atau masalah tertentu, sehingga individu tersebut mampu mengatasi rintangan dan mencapai tujuan yang diharapkan.

${ }_{13}$ Bandura, A., Self Efficacy, The Exercise of Control W. H. Freeman and Company, New York, 1997, hal. 5.

14 Gibson, James. L, dan Donelly, Organizations Behavior Structure Processes Tent Editition, Irwin. McGraw-Hill. 
Hubungan Tingkat Kecerdasan Spiritual Dan Kecerdasan Sosial Terhadap Self Efficacy Pada Siswa Kelas XI di MAN 4 Madiun

Penelitian ini bertujuan untuk menguji hubungan kecerdasan spiritual dan kecerdasan sosial terhadap self efficacy siswa kelas XI di MAN 4 Madiun. Sebagaimana diduga bahwa secara bersama-sama antara kecerdasan spiritual dan kecerdasan sosial memberikan sumbangan yang positif terhadap self efficacy, dan secara sendirisendiri juga memberikan sumbangan positif. Hasil penelitian sebagaimana telah disajikan sebelumnya mendukung hipotesis penelitian.

Dengan demikian, dari hasil penelitian ini memberikan informasi bahwa strategi kecerdasan spiritual dan kecerdasan sosial memberikan kontribusi yang signifikan terhadap selfefficacy siswa, artinya semakin tinggi nilai kecerdasan spiritual dan kecerdasan sosial maka akan semakin tinggi pula self efficacy siswa. Sebaliknya semakin rendah nilai kecerdasan spiritual dan kecerdasan sosial maka akan rendah pula nilai dari self efficacy siswa. Oleh karena itu skor kecerdasan spiritual dan kecerdasan sosial siswa secara bersamasama dapat dijadikan acuan untuk menentukan tinggi rendahnya self efficacy siswa kelas XI di MAN 4 Madiun.

Hubungan antara kecerdasan spiritual dan kecerdasan sosial terhadap self efficacy didukung oleh hasil spss menggunakan regresi linier ganda pada tabel 4.14 yang menyatakan bahwa sig.
$\mathrm{T}$ variabel kecerdasan spiritual sebesar 0,000 dan sig. $T$ variabel kecerdasan sosial sebesar 0,000 .

Dilihat dari data penelitian tabel 4.3, jumlah subjek antara laki-laki dan perempuan lebih banyak perempuan. Jumlah subjek laki-laki berjumlah 13 dan subjek perempuan bejumlah 21 .

Penelitian ini juga dinyatakan valid dan reliabel, hal ini dapat dilihat dari data yang terlampir (lampiran) bahwa seluruh item dari kecerdasan spiritual, kecerdasan sosial dan self efficacy yang masing-masing berjumlah 20 butir item dinyatakan valid. Dikatakan valid karena nilai $r$ hitung lebih besar dari nilai $r$ tabel $(0,329)$. Hasil uji reliabilitas variabel kecerdasan spiritual diperoleh nilai reliabilitas sebesar 0,812 lebih besar dari 0,60. Maka kuesioner kecerdasan spiritual (X1) secara keseluruhan dapat dikatakan reliabel. Variabel kecerdasan sosial diperoleh nilai reliablitas sebesar 0,644 lebih besar dari 0,60. Maka kuesioner kecerdasan sosial (X2) secara keseluruhan dapat dikatakan reliabel dan variabel self efficacy diperoleh nilai 0,765 lebih besar dari 0,60. Maka kuesioner self efficacy $(\mathrm{Y})$ secara keseluruhan dapat dikatakan reliable.

Hasil koefisien korelasi Pearson product moment kecerdasan spiritual sebesar .977. Artinya besar korelasi atau hubungan antara variabel kecerdasan spiritual dan kecerdasan sosial ialah sebesar 0,977 atau berkorelasi sangat kuat karena terletak diantara interval koefisien $0,81-1,00$. 
Hasil penelitian ini bahwa terdapat hubungan yang positif antara kecerdasan spiritual dan kecerdasan sosial terhadap self efficacy pada siswa kelas XI di MAN 4 Madiun. Sehingga apabila kecerdasan spiritual siswa baik dan kecerdasan sosial siswa baik, maka self efficacy siswa akan meningkat. Sebaliknya apabila kecerdasan spiritual siswa tidak baik dan kecerdasan sosial siswa tidak baik, maka self efficacy siswa akan menjadi rendah.

\section{Kesimpulan}

Berdasarkan hasil penelitian dan pembahasan, maka dapat ditarik kesimpulan bahwa:

1. Ada hubungan kecerdasan spiritual terhadap self efficacy siswa kelas XI di MAN 4 Madiun. Kecerdasan spiritual memberikan kontribusi yang signifikan terhadap self efficacy siswa, artinya semakin tinggi nilai kecerdasan spiritual maka akan semakin tinggi pula self efficacy siswa. Sebaliknya semakin rendah nilai kecerdasan spiritual maka akan rendah pula nilai dari self efficacy siswa. Oleh karena itu skor kecerdasan spiritual siswa dapat dijadikan acuan untuk menentukan tinggi rendahnya self efficacy siswa kelas XI di MAN 4 Madiun. Koefisien regresi variabel kecerdasan spiritual sebesar 0.694 mengandung arti untuk setiap pertambahan kecerdasan spiritual sebesar satu satuan akan menyebabkan meningkatnya self
2. Ada hubungan kecerdasan sosial terhadap self efficacy siswa kelas XI di MAN 4 Madiun. Kecerdasan sosial memberikan kontribusi yang signifikan terhadap selfefficacy siswa, artinya semakin tinggi nilai kecerdasan sosial maka akan semakin tinggi pula self efficacy siswa. Sebaliknya semakin rendah nilai kecerdasan sosial maka akan rendah pula nilai dari self efficacy siswa. Oleh karena itu skor kecerdasan sosial siswa dapat dijadikan acuan untuk menentukan tinggi rendahnya self efficacy siswa kelas XI di MAN 4 Madiun. Koefisien regresi variabel kecerdasan sosial sebesar 0.543 mengandung arti untuk setiap pertambahan kecerdasan sosial sebesar satu satuan akan menyebabkan meningkatnya self efficacy sebesar 0.543 .

3. Ada hubungan kecerdasan spiritual dan kecerdasan sosial terhadap self efficacy siswa kelas XI di MAN 4 Madiun. Hasil penelitian ini menunjukkan bahwa terdapat hubungan yang positif antara kecerdasan spiritual dan kecerdasan sosial terhadap self efficacy pada siswa kelas XI di MAN 4 Madiun. Sehingga apabila kecerdasan spiritual siswa baik dan kecerdasan sosial siswa baik, maka self efficacy siswa akan meningkat. Sebaliknya apabila kecerdasan spiritual siswa tidak baik dan kecerdasan sosial siswa tidak baik, maka self efficacy siswa akan menjadi rendah. 


\section{Daftar Pustaka}

Abdullah, Udik, 2005, Meledakkan IESQ Dengan Langkah Takwa $\mathcal{E}$ Tawakal, Jakarta: Zikrul Hakim.

Alwisol, 2007, Psikologi Kepribadian, UMM Press: Malang.

Azzet, Muhaimin, 2010, Mengembangkan Kecerdasan Spiritual Bagi Anak, Jogjakarta: Kata Hati.

Bandura, A., 1997, Self Efficacy, The Exercise of Control W. H. Freeman and Company, New York.

Feist. J., dan G.J Feist, 1998, “Theories of Personality", Fourth Edition, (Boston: Mcgraw-Hill Companies Inc.

Hamzah B., dan Nurdin Mohamad, 2012, Belajar dengan Pendekatan PAILKEM: Pembelajaran Aktif, Inovatif, Lingkungan, Kreatif, Efektif, Menarik, Jakarta: PT Bumi Aksara.

Hariwijaya. M., dan Sutan Surya, 2007, Adventures in Math: Tes IQ Matematika, Yogyakarta: Tugu Publisher, 2007.

Indragiri. A., 2010, Kecerdasan Optimal: Cara Ampuh memaksimalkan Kecerdasan Anak, Jogjakarta: 
Hubungan Tingkat Kecerdasan Spiritual Dan Kecerdasan Dan

Kecerdasan Sosial Terhadap Self Efficacy di MAN 4 Madiun

Oleh: Ullin Nuril Farida \& Badrus 